appearance the chromatophores are found only in the mesoderm. They are single cells with a single large nucleus, appearing to be multi-nuclear only when in degeneration they are invaded by adjacent connective-tissue cells. The author explains the expansion of the cells by the contraction of the radial fibers around it and its contraction by the elasticity of the cell membrane.

Other papers are by Herr Thon on 'The Copulatory Organs of the Hydrachnid Genus Arrhenurus Dugès'; by Dr. Doflein on 'The Inheritance of Cell Characteristics'; by Dr. Simroth on 'Self-Fertilization in Pulmonates'; by Dr. Escherich on 'The Germ Layers in the Muscidæ'; and a history and description of the Graz 'Zoologisch zoolomische Institut,' by Professor L. v. Graff.

The excursion of this session was made to the Austrian Zoological Station at Trieste founded twenty-five years before, largely through the efforts of Professor F. E. Schultze. Since the retirement, in 1896, of Professor Carl Claus, director of the station for many years, the control of the enterprise has been in the hands of a board representing the leading Austrian universities. With the change has come renewed activity, an enlarged building and increased equipment.

\section{UNIVERSITY OF CALIFORNIA.}

A Select Bibliography of Chemistry 1492-1897. By Henry Carrington Bolton. Section VIII. - Academic Dissertations. City of Washington: published by the Smithsonian Institution. 1901. Pp. iv +534 .

This volume-number 1253 of the Smithsonian Miscellaneous Collections-is the third in Dr. Bolton's 'Bibliography of Chemistry.' It is devoted exclusively to those academic dissertations which have been printed independently, and especially to those from the universities of France, Germany, Russia and the United States. The number of the last is exceedingly small, for it seems not yet to be the custom of most American universities to require the printing of theses for the doctor's degree, although much of this work finds its way sooner or later into periodical literature. About seven thousand dissertations are catalogued in the volume, about four-fifths of the titles being German, and a large share of the remainder French.

The reviewer has been interested in tabulating the results of an examination of sample pages, scattered uniformly through the book. From this it appears that nearly five thousand of the dissertations are from German universities, slightly more than a thousand from French, and perhaps seven hùndred and fifty from the Swiss, schools. Of the German universities, Erlangen, Berlin, Göttingen and Leipzig stand first, each furnishing about five hundred titles, while Freiburg and Heidelberg stand considerably lower, and are not very closely followed by Rostock, Tübingen, Jena and Würzburg. Of the Swiss universities, Zürich furnishes about as many titles as Rostock, and Berne as many as Jena. More than half the French dissertations are from l'École de pharmacie de Montpellier, most of the remainder being from Paris and from l'École de pharmacie de Paris, those from the latter being rather more in number than from the former. One hundred and thirteen titles are in Russian, and perhaps nearly as many more are from the University of Dorpat.

This glance reveals to us the position which Germany occupies in the teaching of chemistry, and, if the dissertations of the last few years alone were considered, it would be found that France stands much lower than is shown by the figures above.

Dr. Bolton will receive the thanks, especially of all chemists who are engaged in research, for this addition to his many valuable contributions to bibliography, for it affords access to a very important field of chemical literature, which, for want of an index, has hitherto been practically closed. The original dissertation is often of far more value to the investigator than the re-edited work which appears in the journals. The value of this book is still further increased by reference to those dissertations which are in the libraries of the Geological Survey and of the Smithsonian Institution; and also-this would certainly be missing in no book of Dr. Bolton's-by a very complete index, which fills ninety double-column pages.

While this volume completes the undertaking 
begun by the author in 1888, of preparing a 'Select Bibliography of Chemistry,' he has now in preparation a fourth volume, which will afford him an opportunity of supplying omissions in the three already published.

Jas. Lewis Howe.

WASHINGTON AND LEE UNIVERSITY, Lexington, VA.

Elementary Organic Analysis, The Determination of Carbon and Hydrogen. By Francis Gano Benedict, Ph.D., Instructor in Chemistry in Wesleyan University. Easton, Pa., The Chemical Publishing Co. 1900. 8vo. Pp. 86. Price $\$ 1.00$.

The author states in his preface, "Perhaps no analytical operation is at once so fundamentally important and exasperatingly vexatious as the organic combustion. Notwithstanding this fact, save for the meager statements in one or two of the larger books on organic chemistry, no description of the process of the determination of carbon and hydrogen is accessible to most students. As a rule a knowledge of the operation is chiefly obtained by word of mouth.

" This little manual is presented in the hope that the descriptions of processes here recorded will aid in making this method of analysis more familiar and more satisfactory."

The author states that he has had an experience with over two thousand combustions and that in this book he has embodied such modifications of the general method as have been suggested by that experience.

Some idea of the book will be obtained from the following table of contents: Introduction, preparation of oxygen, compressed oxygen, gasometers or gas holders, air, purifying apparatus, rubber tubing and stoppers, combustion furnaces, combustion tubes, oxidizing agents, filling the combustion tube, boats, absorbing agents, absorbing apparatus, cleaning and weighing absorbing apparatus, weight of material used, burning out the combustion tube, general process of the combustion, combustion of nitrogenous substances, combustion of bodies containing the halogens, combustion of bodies containing sulphur, combustion of bodies containing the alkali metals, combustion of difficultly combustible bodies, combustion of liquids and vola- tile bodies, combustion of explosive bodies, calculation of results, appendix and index.

The book is well printed and of convenient size for laboratory use. For use in teaching students of chemistry the methods of combustion analysis it will be of great value, and even the experienced chemist will find in it many suggestions and new ideas.

W. R. ORNDORFF.

BOOKS RECEIVED.

Cyclopedia of American Horticulture. L. H. BAILEY, assisted by WILhelm Miller. Vol. III., N-Q. New York and London, The Macmillan Company. 1901. Pp. $\mathrm{xv}+1055-1486$. $\$ 5$.

School Geography, Europe and other Continents with Review of North America. RALPH S. TARR and Frank M. McMurry. New York, The Macmillan Company. 1901. Third book. Pp. $x x+574$.

The Limits of Evolution and olher Essays illustrating the Metaphysical Theory of Personal Idealism. G. H. Howison. New York and London, The Macmillan Company. 1901. Pp. xxxv + 396. $\$ 1.60$.

\section{SCIENTIFIC JOURNALS AND ARTICLES.}

The American Naturalist for April has as its first article a paper by B. Arthur Bensley, on 'A Theory of the Origin and Evolution of the Australian Marsupialia.' The adaptive modification of their teeth and feet are compared with those of placental mammals, the author concluding that the marsupials were differentiated from Didelphyd forms, but adding no evidence to show from what direction they entered Australia. R. M. Strong presents in detail 'A Quantitative Study of Variation in the Smaller North American Shrikes,' and Frank Russell describes 'A New Instrument for Measuring Torsion' in the long bones of the human skeleton, but applicable to other purposes. The valuable series of 'Synopses of North-American Invertebrates' is resumed, the present paper, the fourteenth of the series, by C. W. Hargitt, being devoted to 'The Hydromedusæ, Part I.' The number contains the quarterly record of gifts to institutions, and the appointments, retirements and deaths of scientific workers.

The Journal of Physical Chemistry, March, 1901, 'On the Dielectric Constants of Nitrils,' by Herman Schlundt. The fact that solutions 